ANNUAL SUMMARY

\title{
Eastern North Pacific Hurricane Season of 2010
}

\author{
STACY R. STEWART AND JOHN P. CANGialosi \\ National Hurricane Center, Miami, Florida
}

(Manuscript received 29 June 2011, in final form 6 November 2011)

\begin{abstract}
The 2010 eastern North Pacific hurricane season was one of the least active seasons on record. Only seven named storms developed, which is the lowest number observed at least since routine satellite coverage of that basin began in 1966. Furthermore, only three of those storms reached hurricane status, which is also the lowest number of hurricanes ever observed in the satellite-era season. However, two tropical storms made landfall: Agatha in Guatemala and Georgette in Mexico, with Agatha directly causing 190 deaths and moderate to severe property damage as a result of rain-induced floods and mud slides. On average, the National Hurricane Center track forecasts in the eastern North Pacific for 2010 were quite skillful.
\end{abstract}

\section{Introduction}

The 2010 eastern North Pacific hurricane season continued the trend of generally quieter than average seasons since 1995 (Fig. 1; Table 1) (Wang and Lee 2009). A total of seven tropical storms developed, of which three became hurricanes, including two major hurricanes [maximum 1-min winds of greater than $96 \mathrm{kt}\left(1 \mathrm{kt}=0.5144 \mathrm{~m} \mathrm{~s}^{-1}\right)$, corresponding to category 3 or greater on the SaffirSimpson Hurricane Wind Scale (Saffir 1973; Simpson 1974; Schott 2012)]. In addition, five tropical depressions formed that did not strengthen into tropical storms.

The numbers of hurricanes and major hurricanes were below the 1971-2009 averages of nine and four, respectively, and the total of three hurricanes was the lowest observed in the satellite era. Despite the relative dearth of tropical cyclone activity, Celia was a long-lived category-5 hurricane that tied Hurricane Ava as the strongest June hurricane on record in the eastern North Pacific (since reliable records began in 1971).

A parameter routinely used to gauge the overall activity of a season is the "accumulated cyclone energy" (ACE) index (Bell et al. 2000). The ACE index, which accounts for the frequency, intensity, and duration of the season's storms, is calculated by summing the squares of

Corresponding author address: Stacy R. Stewart, National Hurricane Center, 11691 SW 17th Street, Miami, FL 33165.

E-mail: stacy.r.stewart@noaa.gov the maximum sustained wind speed at 6-h intervals for all (sub)tropical storms and hurricanes. The ACE for the 2010 season was $50 \times 10^{4} \mathrm{kt}^{2}$, or about $46 \%$ of the long-term (1971-2009) median value of $109 \times 10^{4} \mathrm{kt}^{2}$. Two hurricanes, Celia and Darby, accounted for $70 \%$ of the total ACE for the season. The 2010 season had the third lowest ACE since 1971, ahead of only 1977 and 2007. Tropical cyclone activity in the eastern North Pacific has generally remained below the long-term mean since 1995 except during seasons when an El Niño event was occurring. The below-average tropical cyclone activity observed in 2010 appears to be related to the effects of a moderately strong La Niña event, which resulted in moderate to strong easterly vertical wind shear across much of the eastern North Pacific basin.

During 2010, below-normal sea surface temperatures, a well-known characteristic of La Niña events, were observed in the tropical and subtropical eastern Pacific (Fig. 2), and these conditions may have also contributed to the overall decrease in tropical cyclone activity in the basin. It is worth noting that all but one of the named storms in 2010 formed east of $106^{\circ} \mathrm{W}$ (Fig. 1) where the greatest depth of warm water was located, and four of the seven of tropical storms formed near the Gulf of Tehuantepec.

Composite data from the National Centers for Environmental Prediction (NCEP)-National Center for Atmospheric Research (NCAR) reanalysis (Kalnay et al. 1996) suggest that the eastward displacement of the primary genesis region may have been associated with the 


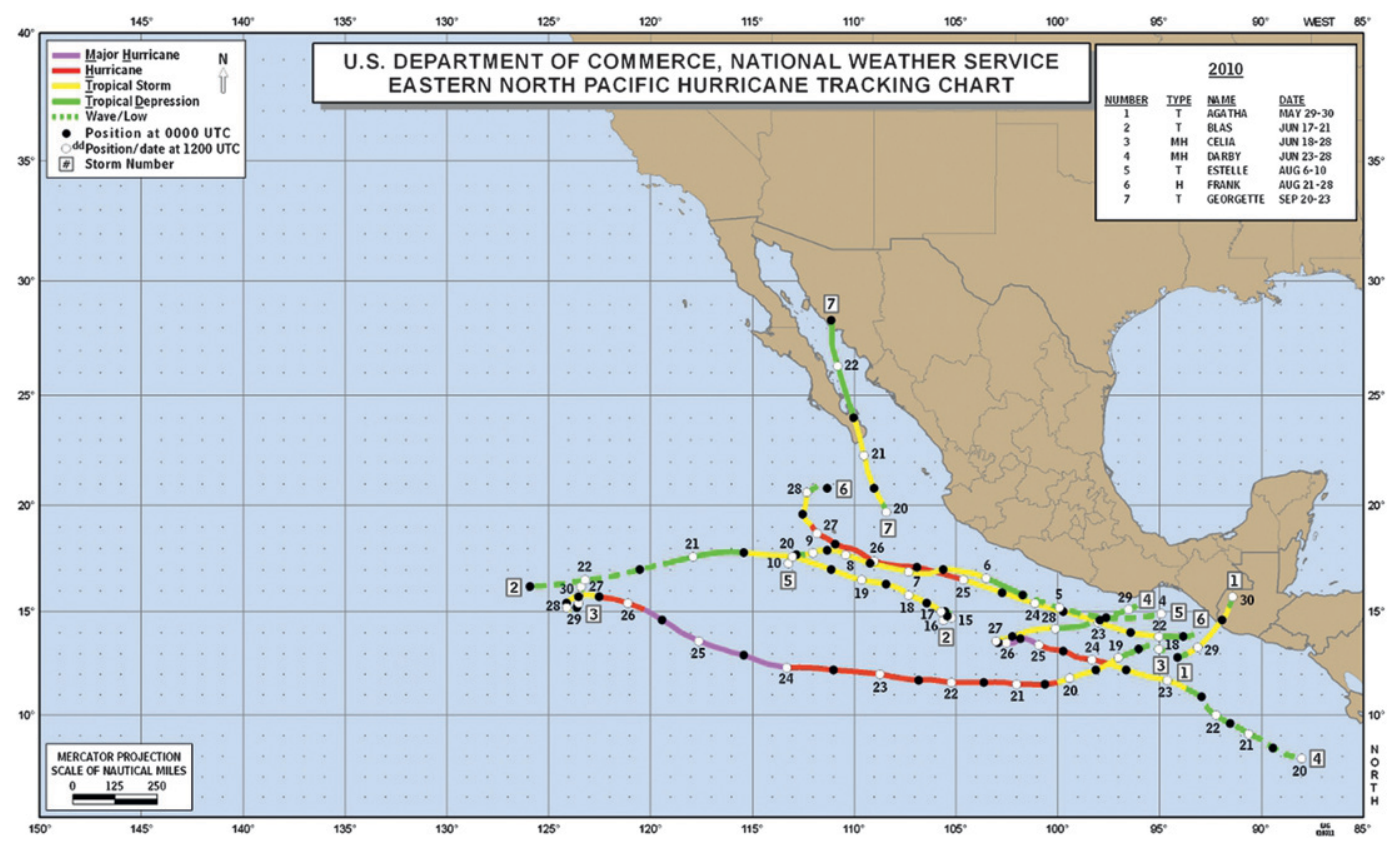

FIG. 1. Tracks of the tropical storms and hurricanes in the eastern North Pacific basin in 2010, including remnant low stages.

large-scale negative 200-hPa velocity potential anomaly (Fig. 3) that was centered near the Pacific coast of Mexico along $100^{\circ} \mathrm{W}$ longitude. The eastward displacement of this favorable large-scale, upper-level divergence pattern could have contributed to the decrease in the number of storms because of its proximity to the rugged coastal mountain ranges of Mexico, since high terrain is well known to disrupt the circulation of incipient disturbances. In addition to land interaction inhibiting development, tropical disturbances during 2010 encountered abovenormal easterly vertical wind shear conditions (Fig. 4) over most of the eastern and central portions of the basin (east of $130^{\circ} \mathrm{W}$ and north of $10^{\circ} \mathrm{N}$ ).

TABLE 1. 2010 eastern North Pacific hurricane season statistics.

\begin{tabular}{lccccc}
\hline \hline Name & Class* & Dates** & $\begin{array}{c}\text { Max } \\
\text { 1-min } \\
\text { wind (kt) }\end{array}$ & $\begin{array}{c}\text { Min sea } \\
\text { level pressure } \\
\text { (mb) }\end{array}$ & $\begin{array}{c}\text { Direct } \\
\text { deaths }\end{array}$ \\
\hline Agatha & TS & 29-30 May & 40 & 1001 & 190 \\
Blas & TS & 17-21 Jun & 55 & 992 & \\
Celia & MH & 18-28 Jun & 140 & 921 & \\
Darby & MH & 23-28 Jun & 105 & 959 & \\
Estelle & TS & 6-10 Aug & 55 & 994 & \\
Frank & H & 21-28 Aug & 80 & 978 & \\
Georgette & TS & 20-23 Sep & 35 & 999 & \\
\hline
\end{tabular}

* TS = tropical storm, wind speed 34-63 kt (17-32 $\left.\mathrm{m} \mathrm{s}^{-1}\right) ; \mathrm{H}=$ hurricane, wind speed $64 \mathrm{kt}\left(33 \mathrm{~m} \mathrm{~s}^{-1}\right)$ or higher; $\mathrm{MH}=$ major hurricane, hurricane with maximum winds $96 \mathrm{kt}\left(49 \mathrm{~m} \mathrm{~s}^{-1}\right)$ or higher.

** Dates are based on UTC and include the tropical depression stage but exclude the remnant low stage.
The 2010 season began four days before the median date for the first named storm, with Agatha developing on 29 May (Fig. 1). Unlike the 2009 season, the months of July, August, and September 2010 were unusually inactive, with only three named storms and one hurricane forming. The season ended earlier than usual when Georgette dissipated on 23 September, which is a month before the median ending date of 23 October.

The second section focuses on data used for tropical cyclone analysis. Section 3 provides individual narratives of tropical cyclone life cycles for all named storms,

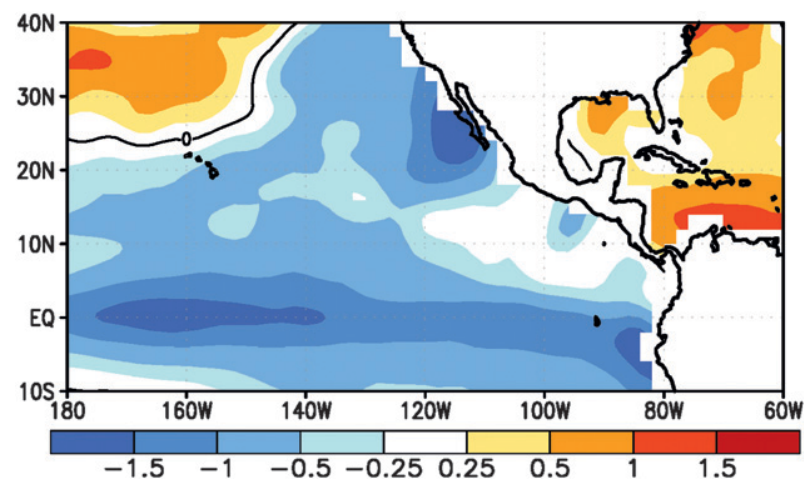

FIG. 2. Composite sea surface temperature (SST) anomaly for July to October 2010 from the NOAA Optimum Interpolation SST analysis. Anomaly computed from the 1981-2010 mean. Image provided by the NOAA/Earth System Research Laboratory (ESRL)/Physical Sciences Division, Boulder, Colorado, from their website (http://www.esrl.noaa.gov/psd). 


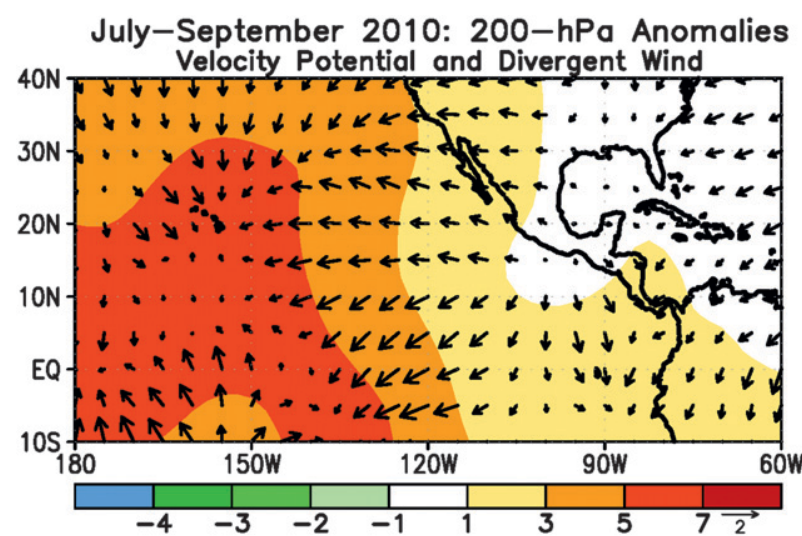

July-September 2010

200-850-hPa Vertical Wind Shear Magnitude and Vector
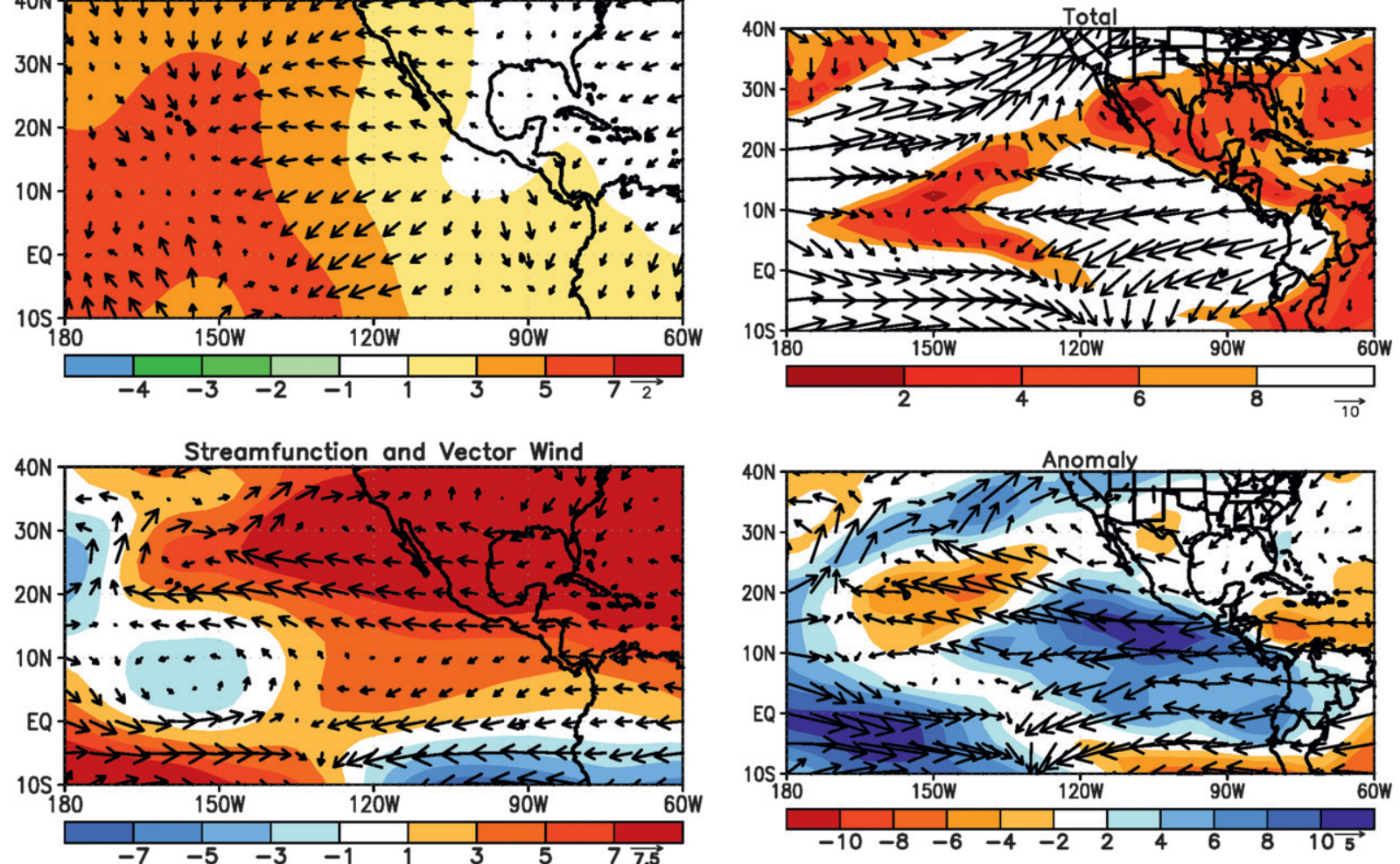

FIG. 3. (top) Composite of July-September 2010 200-hPa velocity potential anomaly (shaded, $\mathrm{m}^{2} \mathrm{~s}^{-1}$ ) and divergent wind anomaly (arrows, $\mathrm{m} \mathrm{s}^{-1}$, scale given in lower right). (bottom) JulySeptember 2010 200-hPa streamfunction anomaly (shaded, $\mathrm{m}^{2} \mathrm{~s}^{-1}$ ) and nondivergent wind anomaly (arrows, $\mathrm{m} \mathrm{s}^{-1}$, scale given in lower right) from the NCEP-NCAR reanalysis. Anomaly computed from 1981-2010 mean.

followed by a description in section 4 of tropical depressions that did not strengthen further. The fifth and final section discusses and critiques the verification of National Hurricane Center (NHC) track and intensity forecasts for the 2010 season.

\section{Data}

The individual cyclone summaries that follow are based on NHC poststorm meteorological analyses of a wide variety of data described below. These analyses result in the creation of a "best track" database for each cyclone, consisting of 6-hourly representative estimates of the cyclone's center position, maximum sustained (1-min average) surface $(10 \mathrm{~m})$ wind, minimum sea level pressure, and the maximum extent of 34-, 50-, and 64-kt winds in each of four quadrants around the cyclone's center. The life cycle of each cyclone (as indicated by the dates given in Table 1) includes the tropical depression stage but does not include remnant low or extratropical

FIG. 4. (top) Composite mean of July to September 2010200 850-hPa vertical wind shear magnitude (shaded, $\mathrm{m} \mathrm{s}^{-1}$ ) and vector (scale given in lower right). (bottom) July-September 2010200 $850-\mathrm{hPa}$ vertical wind shear anomaly magnitude (shaded, $\mathrm{m} \mathrm{s}^{-1}$ ) and vector (scale given in lower right) from the NCEP-NCAR reanalysis. Anomaly computed from the 1981-2010 mean.

stages. The tracks and basic statistics for the season's tropical storms and hurricanes are given in Fig. 1 and Table $1{ }^{1}$

Observations of eastern North Pacific tropical cyclones are almost exclusively obtained from satellites, with the National Oceanic and Atmospheric Administration (NOAA) Geostationary Operational Environmental Satellites (GOES) serving as the primary platform. GOES-East and GOES-West provide the visible and infrared imagery that serves as input for intensity estimates based on the Dvorak classification technique (Dvorak 1984; Velden et al. 2006). Subjective Dvorak intensity estimates utilized by NHC are performed by NHC's Tropical Analysis and Forecast Branch (TAFB) and the Satellite

\footnotetext{
${ }^{1}$ Tabulations of the 6-hourly best track positions and intensities can be found in the NHC Tropical Cyclone Reports, available at http://www.nhc.noaa.gov/pastall.shtml. These reports contain storm information omitted here due to limitations of space, including additional surface observations and a forecast and warning critique.
} 
Analysis Branch (SAB) in Camp Springs, Maryland. The advanced Dvorak technique (ADT; Olander and Velden 2007) is an objective method that also provides satellite intensity estimates of tropical cyclones using geostationary imagery.

Geostationary imagery is occasionally supplemented by passive microwave imagery from NOAA polarorbiting satellites, Defense Meteorological Satellite Program (DMSP) satellites, the U.S. Navy's WindSat, and National Aeronautics and Space Administration (NASA) satellites that include the Tropical Rainfall Measuring Mission (TRMM) and Aqua instruments. Such imagery is useful for tracking tropical cyclones and assessing their structure (e.g., Hawkins et al. 2001). Ocean surface vector wind retrievals from the European Space Agency's Advanced Scatterometer (ASCAT) were useful for analysis. Careful interrogation of scatterometer data provides estimates of the location, intensity, and outer wind radii (e.g., Brennan et al. 2009). In addition, these data can be helpful in resolving whether a disturbance has acquired a closed surface circulation. Information about the thermal structure of cyclone cores is provided by the Advanced Microwave Sounder Unit (AMSU; Demuth et al. 2006; Brueske and Velden 2003). Intensity estimates derived from these AMSU data can sometimes be superior to Dvorak classifications (Herndon and Velden 2004).

Ships and buoys occasionally provide important in situ observations. For systems posing a threat to land, direct measurements from reconnaissance aircraft are often available. However, since all of the hurricanes that formed remained well away from any landmasses in 2010, the 53rd Weather Reconnaissance Squadron of the U.S. Air Force Reserve Command (AFRC) did not fly any reconnaissance missions into eastern North Pacific tropical cyclones this year. Land-based radars from the meteorological service of Mexico were also useful for monitoring systems during 2010. For a more complete description of the observational platforms used at the NHC, see Rappaport et al. (2009).

\section{Individual storm summaries}

\section{a. Tropical Storm Agatha, 29-30 May}

The genesis of Agatha was the result of a complex interaction between multiple tropical waves. The primary contributor to the development process was a tropical wave that moved westward from the coast of Africa on 8 May and crossed Central America into the eastern North Pacific on 21 May. The associated thunderstorm activity increased on 24 May a few hundred miles west of Costa Rica, and a broad low pressure area formed along the wave axis the next day. Little development occurred during the next couple of days as the weak low drifted slowly westward a few hundred miles south of the Gulf of Tehuantepec. During this time, two other tropical waves crossed Central America and were absorbed into the broad low pressure system.

ASCAT data on 28 May showed the circulation of the low becoming better defined, and it is estimated that a tropical depression formed near 0000 UTC 29 May about $155 \mathrm{n}$ mi southwest of Tapachula, Mexico. The depression moved northeastward in deep-layer southwesterly flow between a mid/upper-level trough over the Gulf of Mexico and a mid/upper-level ridge over the western Caribbean Sea. A second ASCAT overpass indicated the cyclone had strengthened into a tropical storm about $6 \mathrm{~h}$ after genesis. Agatha reached a peak intensity of $40 \mathrm{kt}$ at 1800 UTC 29 May and then made landfall with the same intensity near Champerico, Guatemala, at 2230 UTC that day (Fig. 5). The surface circulation of Agatha weakened as it continued northeastward into the Sierra Madre Mountains and dissipated on 30 May over western Guatemala. The cyclone's midlevel remnants may have contributed to the formation of a short-lived surface low over the northwestern Caribbean Sea on 31 May.

The main impact from Agatha was widespread heavy rain through portions of Central America. Rainfall totals of 100-200 mm were widespread over southern Guatemala on 29 May, with Montufar reporting a 24-h total of $426 \mathrm{~mm}$. Heavy rainfall also occurred in El Salvador, with Ilopango reporting a total of $208 \mathrm{~mm}$. The rains from Agatha were part of a prolonged period of heavy rain in Central America during 25-30 May. During this period, Mazatenango, Guatemala, reported $566 \mathrm{~mm}$ of rain.

Tropical cyclone landfalls in Guatemala are rare events. In the eastern North Pacific tropical cyclone database that extends back to 1949, only one other tropical storm has made landfall in Guatemala: Simone on 19 October 1968. In addition, Tropical Storm Barbara made landfall just west of the Mexico-Guatemala border, not far from where Agatha made landfall, on 2 June 1997.

Agatha's heavy rains caused widespread floods and mud slides in Guatemala, Honduras, and El Salvador, which resulted in many fatalities. While there is uncertainty, the direct death toll appears to be 190. The National Coordinator of Disaster Reduction of Guatemala reported that 160 people died in that country from the effects of Agatha, with an additional 47 people missing. Reports from the U.S. Agency for International Development indicate an additional 18 fatalities in Honduras and 12 in El Salvador.

The floods and mud slides caused an estimated \$1.1 billion (USD) in property damage, with $\$ 982$ million in 


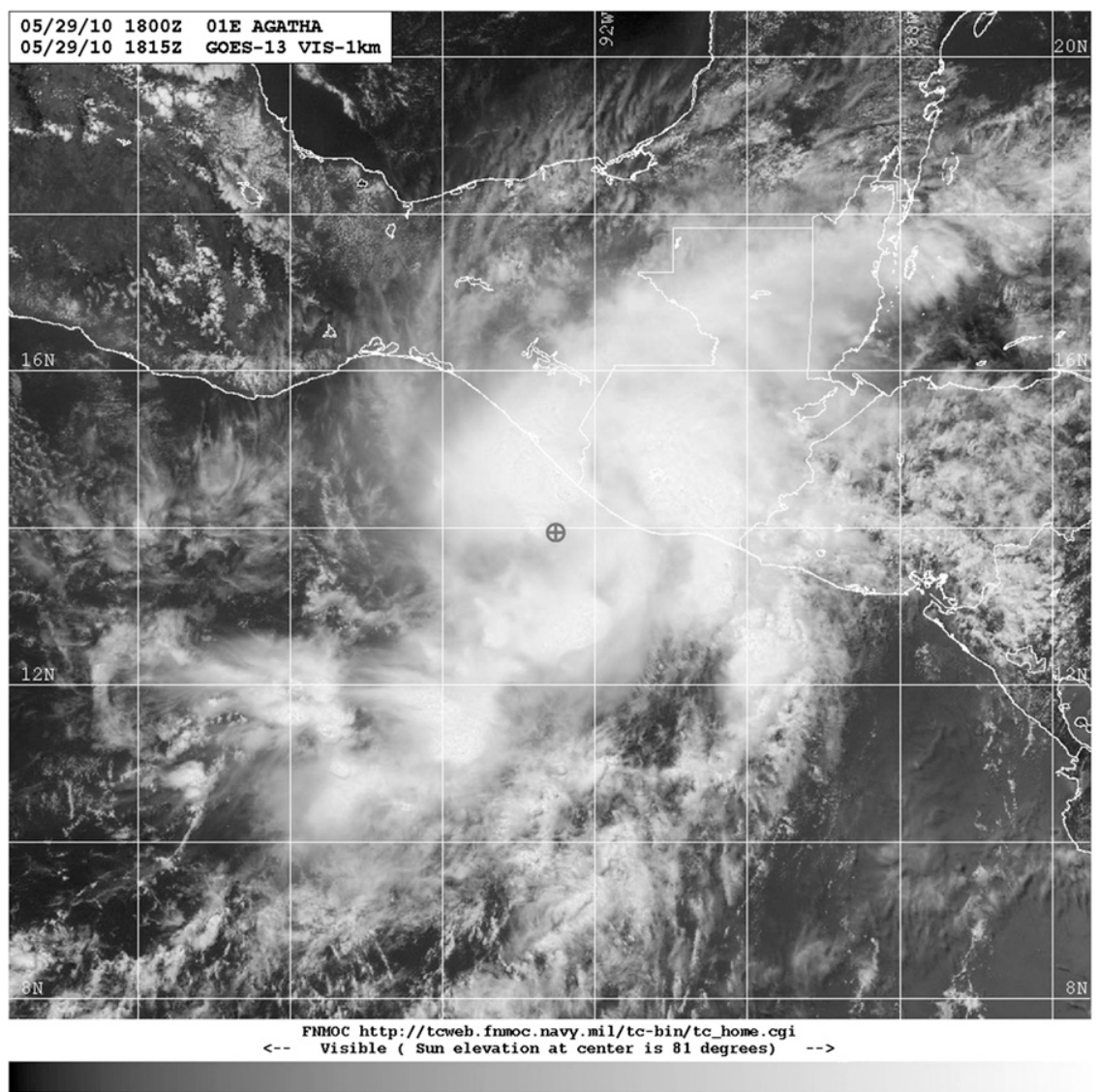

FIG. 5. GOES-13 visible image of Agatha at 1815 UTC 29 May 2010, the time of the cyclone's peak intensity about $4 \mathrm{~h}$ prior to landfall in Guatemala (circled cross indicates lowlevel center position). Image courtesy of the U.S. Navy Fleet Numerical Oceanography and Meteorology Center satellite data tropical cyclone webpage (https://www.fnmoc.navy.mil/ tcweb/cgi-bin/tc_home.cgi).

Guatemala and \$112 million in El Salvador. A spectacular example of damage documented by the news media was a 20-m wide sinkhole that opened up in Guatemala City, destroying several buildings in the process.

\section{b. Tropical Storm Blas, 17-21 June}

Blas formed from a tropical wave that exited the west coast of Africa on 30 May and crossed the Atlantic over the next 10 days. The wave produced very little shower activity during that time, but deep convection increased when the system moved across Central America on 9 and 10 June. An area of low pressure developed along the wave axis by 13 June, but it was another $48 \mathrm{~h}$ before geostationary and microwave imagery indicated that the system had acquired a well-defined surface center of circulation. The disturbance meandered from 15 to 17 June, and convective activity was not persistent enough for the low pressure system to be classified as a tropical cyclone. The low began to maintain organized deep convection early on 17 June, and it is estimated that a tropical depression formed around 0600 UTC that day, centered about $265 \mathrm{n}$ mi south-southwest of Manzanillo, Mexico. The cargo ship Maersk Dhahran (call sign A8PX5) reported 40-kt winds near the center at 1500 UTC that day, indicating that the depression had strengthened into a tropical storm by 1200 UTC.

After achieving tropical storm status, Blas accelerated toward the northwest and then west-northwest as a midtropospheric ridge built westward from Mexico over the eastern North Pacific waters. About 15 to $20 \mathrm{kt}$ of $850-200-\mathrm{mb}$ northeasterly to easterly vertical wind shear prevented the cyclone from strengthening over the 24 -h period ending at 1800 UTC 18 June. The shear then decreased to $10-15 \mathrm{kt}$, which allowed the lowlevel circulation center to become embedded under the northeastern edge of the deep convective cloud mass, and Blas intensified to its estimated peak intensity of $55 \mathrm{kt}$ by 1200 UTC 19 June. Shortly thereafter, the 
storm began to move into a more stable environment and over sea surface temperatures less than $26^{\circ} \mathrm{C}$, and the associated shower and thunderstorm activity diminished significantly. Blas weakened to a tropical depression around 0000 UTC 21 June and degenerated into a remnant low at 1800 UTC that day when it was centered about $620 \mathrm{n}$ mi west-southwest of the southern tip of Baja California. The remnant low moved generally westward for the next $24 \mathrm{~h}$ and dissipated after 0000 UTC 23 June.

\section{c. Hurricane Celia, 18-28 June}

Celia originated from a tropical wave that moved off the African coast on 5 June. The wave moved uneventfully westward across the tropical Atlantic and Caribbean Sea, reaching the eastern North Pacific by 17 June. Showers and thunderstorms associated with the slowmoving wave increased later that day, and a surface low pressure area developed along the wave axis around 0600 UTC 18 June about $230 \mathrm{n}$ mi southeast of Puerto Escondido, Mexico. A well-defined curved band of deep convection formed on the north side of the circulation during the next 6 to $12 \mathrm{~h}$, and a tropical depression formed around 1800 UTC 18 June about $320 \mathrm{n}$ mi southeast of Acapulco, Mexico. Although the wind field became better defined during the hours after genesis, deep convection associated with the depression nearly dissipated by 0000 UTC 19 June. The convection redeveloped within the next several hours, and the organization of the cloud pattern steadily improved. An 1145 UTC Special Sensor Microwave Imager (SSM/I) satellite overpass on 19 June indicated the presence of a closed low- to midlevel convective ring, and it is estimated that the depression reached tropical storm status around this time while centered about $290 \mathrm{n}$ mi south-southeast of Acapulco.

Celia moved slowly west-southwestward to westward over the next few days, embedded within low-level westerly flow and moderate northeasterly flow at middle and upper levels associated with a strong subtropical ridge to its north. Although the differing flow between these levels created moderate northeasterly vertical wind shear over the cyclone, Celia steadily intensified after reaching tropical storm strength and is estimated to have acquired hurricane status by 1800 UTC 20 June while centered about $310 \mathrm{n}$ mi south of Acapulco. However, the northeasterly vertical shear became stronger during the next several days and prevented Celia from intensifying significantly, with the intensity remaining between 65 and $85 \mathrm{kt}$ from 1800 UTC 21 June until 1200 UTC 23 June.

Celia began moving just north of due west early on 23 June with some increase in forward speed to the south of a deep layer ridge. A relaxation of the northeasterly shear resulted in a brief period of significant intensification from an intensity of $75 \mathrm{kt}$ at 0600 UTC to $95 \mathrm{kt}$ at 1800 UTC that day. The convective structure of the cyclone soon became asymmetric; a well-defined eye that had formed earlier began to disappear in response to a renewed increase in the northeasterly vertical wind shear. The weakening trend only continued for another 6 to $12 \mathrm{~h}$, after which the inner core convection reorganized and convective cloud tops cooled again. A decrease in vertical wind shear occurred around this time, and Celia began another period of rapid intensification as it turned west-northwestward in response to an amplifying mid- to upper-level trough that weakened the subtropical ridge to its north. The hurricane strengthened from 90 to $140 \mathrm{kt}$ in an 18-h period, with an estimated peak intensity occurring around 0000 UTC 25 June (Fig. 6).

During the next couple of days Celia rapidly weakened as it moved over progressively cooler waters and entered a more stable thermodynamic environment. The cyclone fell below major hurricane strength early on 26 June and weakened to a tropical storm by 0000 UTC 27 June while centered about $830 \mathrm{n}$ mi west-southwest of the southern tip of Baja California. The weakening cyclone abruptly slowed down on 27 June as the western extension of the ridge to its north eroded further, in response to an amplifying midtropospheric trough near the U.S. West Coast. As Celia lost nearly all of its deep convection and became a shallow cyclone, it slowed even further and began drifting west-southwestward to southwestward in weak low-level steering flow on 28 September. Celia then became embedded in a low-level westerly flow and turned east-northeastward, completing a counterclockwise loop and degenerating into a remnant low pressure system about $900 \mathrm{n}$ mi west-southwest of the southern tip of Baja California at 0000 UTC 29 June. The remnant low of Celia drifted northward for another day before dissipating.

\section{d. Hurricane Darby, 23-28 June}

The vigorous tropical wave that spawned Hurricane Darby exited the west coast of Africa on 8 June; deep convection associated with the wave, however, waned significantly after $24 \mathrm{~h}$ over water. The wave moved steadily westward for the next 11 days, producing little or no convection until it reached the far eastern North Pacific on 19 June. On 20 June, a small low pressure system developed along the wave axis about $150 \mathrm{n} \mathrm{mi}$ to the southwest of Costa Rica as the disturbance slowed and began moving toward the west-northwest. Thunderstorms gradually increased and became better organized, and it is estimated that a tropical depression formed by 0000 


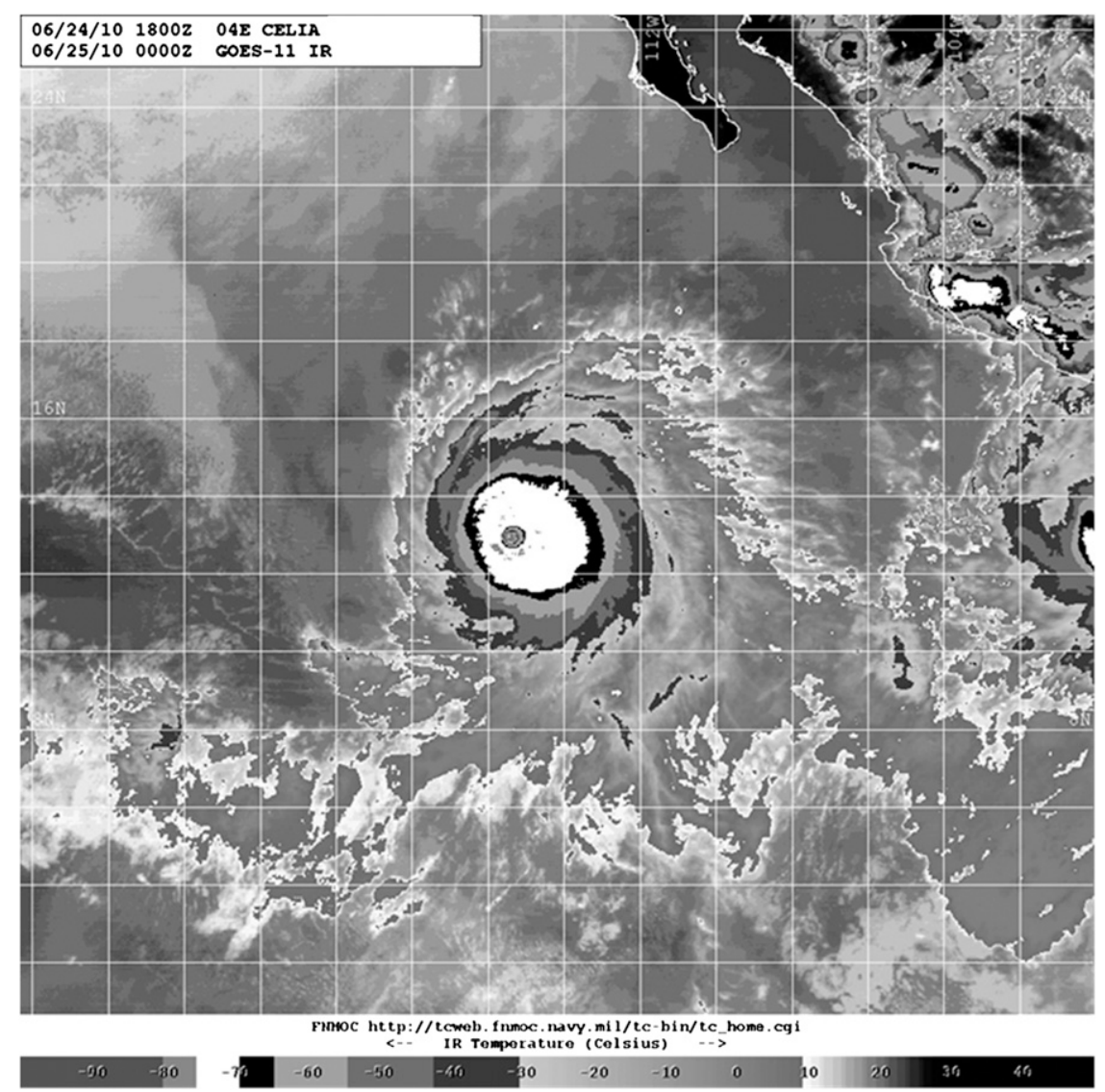

FIG. 6. GOES-11 infrared image of Celia with Dvorak enhancement curve at 2345 UTC 24 Jun 2010, at the time of the cyclone's peak intensity. Image courtesy of the U.S. Navy Fleet Numerical Oceanography and Meteorology Center satellite data tropical cyclone webpage (https://www.fnmoc.navy.mil/tcweb/cgi-bin/tc_home.cgi).

UTC 23 June, centered about $330 \mathrm{n}$ mi south-southeast of Salina Cruz, Mexico.

The relatively small tropical cyclone continued in a west-northwestward direction for the next three days with a gradual decrease in forward speed, from $10 \mathrm{kt}$ down to less than $5 \mathrm{kt}$ by 26 June. During this time, Darby remained in a low vertical wind shear environment and underwent two periods of rapid intensification-from 30 to $60 \mathrm{kt}$ between 0000 UTC 23 June and 0000 UTC 24 June, and then from 75 to $105 \mathrm{kt}$ between 1800 UTC 24 June and 1800 UTC 25 June. The west-northwestward motion kept the center of the cyclone about $200 \mathrm{n}$ mi off of the coast of Mexico. Even near its peak intensity of $105 \mathrm{kt}$ (Fig. 7), tropical-storm-force winds only extended outward about $60 \mathrm{n} \mathrm{mi}$ to the northeast of the center. Darby possessed a very small eye (diameter $<10 \mathrm{n} \mathrm{mi}$ ). The small size of the cyclone also likely played a significant role in the two rapid intensification episodes.

After Darby reached its peak intensity about $215 \mathrm{n} \mathrm{mi}$ south-southwest of Acapulco, the hurricane turned westward and its forward speed slowed. Early on 27 June, a long fetch of low- to mid-level westerly winds flowing into the large circulation of Atlantic basin Hurricane Alex, which was located well to the northeast over the Gulf of Mexico, caused Darby to reverse its course and begin moving slowly east-northeastward as it was drawn into the outer circulation of Alex.

During this time, Darby began to weaken because of northeasterly vertical wind shear created by the extensive outflow from Hurricane Alex. Darby became a tropical storm around 0600 UTC 27 June and weakened to a tropical depression the next day around 1200 UTC 28 June when it was located more than $150 \mathrm{n}$ mi south of Acapulco. The cyclone degenerated into a remnant low pressure system just $6 \mathrm{~h}$ later as the strong vertical shear conditions stripped away deep convection from the circulation. The remnant low continued to move slowly east-northeastward into the Gulf of Tehuantepec, where a brief burst of convection redeveloped early on 29 June south of the low-level center. However, the convection 


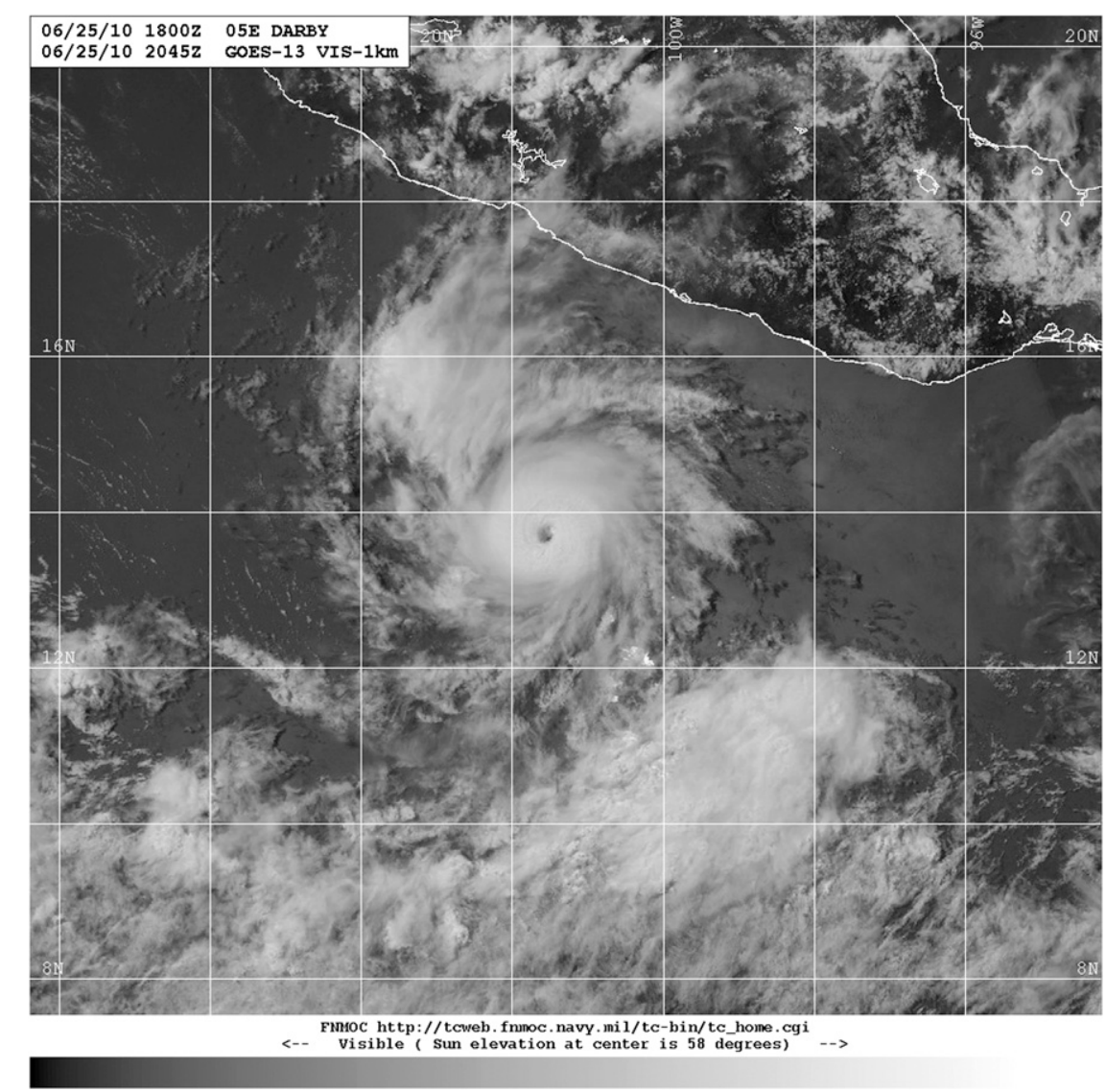

FIG. 7. GOES-13 visible image of Darby at 2045 UTC 25 Jun 2010, at the time of the cyclone's peak intensity. Image courtesy of the U.S. Navy Fleet Numerical Oceanography and Meteorology Center satellite data tropical cyclone webpage (https://www.fnmoc.navy.mil/tcweb/cgibin/tc_home.cgi).

did not persist and the low dissipated after 1800 UTC that same day offshore of the southern coast of Mexico.

\section{e. Tropical Storm Estelle, 6-10 August}

The wave that spawned Estelle departed the African coast on 22 July without much thunderstorm activity. Convection remained minimal for much of the next week until 29 July when the wave interacted with an upper-level trough over the eastern Caribbean Sea. Some organization of the system was noted in satellite images over the western Caribbean Sea, but the wave moved inland over Central America on 2 August before any significant development could occur. Thunderstorms increased over a considerable area in southeastern Mexico by late on 3 August, with a thunderstorm complex moving southward from the Isthmus of Tehuantepec into the far eastern North Pacific Ocean. After the large complex dissipated, a weak convectively induced low pressure system remained behind just south of the Gulf of Tehuantepec the next day. Moving west-northwestward, the low gradually acquired organized convection and by 0000 UTC 6 August, a tropical depression had formed about $120 \mathrm{n}$ mi southwest of Acapulco, Mexico.

Twelve hours later, the depression became a tropical storm and slowly intensified farther. Early on 7 August, microwave satellite images indicated that the center of Estelle had reformed to the southwest of the previous position, but the overall system continued moving toward the west and west-northwest. The tropical storm reached a peak intensity of $55 \mathrm{kt}$ around 0000-0600 UTC 8 August, as indicated by satellite intensity estimates and the presence of a midlevel eye feature in microwave satellite data. Estelle then gradually decreased in strength because of cooler waters, a more stable environment, and southeasterly vertical wind shear. The cyclone turned westward and its forward speed slowed by late on 8 August. Vertical shear further increased the next day, and Estelle weakened into a tropical depression near 1800 UTC 9 August. Twelve hours later, it degenerated to a remnant low pressure system, centered about $370 \mathrm{n} \mathrm{mi} \mathrm{south-southwest} \mathrm{of} \mathrm{the}$ 
southern tip of Baja California. The remnants of Estelle drifted slowly southeastward and were absorbed by the intertropical convergence zone (ITCZ) late on 10 August.

\section{f. Hurricane Frank, 21-28 August}

Frank originated from a tropical wave that was difficult to trace after it moved off the west coast of Africa. It was first identified again on 15 August when a large area of showers, accompanied by a low-level cyclonic wind shift, was noted near the southern Windward Islands. Deep convection increased slightly as the wave crossed Central America on 19 August, but the activity did not become concentrated until the morning of 21 August over the Gulf of Tehuantepec as a surface low pressure system formed and gradually became better defined. The system developed curved convective bands while the thunderstorm activity increased near a low-level circulation center, and it is estimated that a tropical depression formed at 1800 UTC 21 August about 180 n mi southeast of Salina Cruz.

Embedded within weak steering currents, the depression drifted westward for the next day with no significant change in structure. The cloud pattern gradually became better organized, and subjective Dvorak satellite intensity estimates indicated that the depression became a tropical storm at 1200 UTC 22 August. Frank began to move westward at about $6 \mathrm{kt}$ on a track parallel to the coast of Mexico with some increase in intensity. However, strong northeasterly vertical wind shear eroded the convection, and the cyclone weakened on 23 August. There was a resurgence of thunderstorm activity on 24 August and gradual improvement in the cloud pattern. An Advanced Microwave Scanning Radiometer for Earth Observing System (AMSR-E) 36-GHz image at 0834 UTC 25 August showed a closed ring of convection resembling an eyewall, and the ring was later observed in TRMM microwave data at 1718 UTC. It is estimated that Frank became a hurricane at 1200 UTC 25 August.

Frank's eye was only apparent intermittently in conventional satellite imagery during the next day or so, although microwave satellite data revealed that the eye had persisted under the cyclone's thick cirrus canopy. Frank reached its estimated peak intensity of $80 \mathrm{kt}$ at 1800 UTC 26 August when located about $300 \mathrm{n}$ mi south of the southern tip of Baja California. At that time, visible satellite images and microwave data clearly showed a small but distinct eye embedded within a circular area of deep convection. A couple of hours later, the cloud pattern quickly deteriorated, and the eye disappeared, indicating that the weakening process had begun. Frank moved toward the northwest and lost all its associated convection when it reached cooler waters and encountered strong vertical shear. The cyclone became a remnant low pressure system at 1800 UTC 28 August about $200 \mathrm{n} \mathrm{mi} \mathrm{southwest} \mathrm{of} \mathrm{the} \mathrm{southern} \mathrm{tip} \mathrm{of} \mathrm{Baja}$ California.

\section{g. Tropical Storm Georgette, 20-23 September}

The genesis of Georgette was associated with a tropical wave that exited the west coast of Africa on 1 September. The wave was difficult to identify as it moved across the tropical Atlantic, but convection increased when the wave approached the Lesser Antilles on 9 September. While the system moved through the Caribbean Sea, it was associated with the formation of Atlantic Hurricane Karl on 14 September (Beven and Blake 2012). The southern portion of the wave continued westward and crossed Mexico on 17-18 September before entering the eastern North Pacific on 19 September. Thunderstorm activity increased on 19 and 20 September and a well-defined circulation center became apparent in satellite imagery around 1200 UTC 20 September, indicating the formation of a tropical depression about $210 \mathrm{n}$ mi southsoutheast of Cabo San Lucas. Shortly after that time, deep convection diminished markedly as a result of strong easterly vertical wind shear. Even with a reduction in the deep convection, however, ASCAT scatterometer wind data indicated that maximum winds had increased to $35 \mathrm{kt}$ by 1800 UTC that day, and the depression became a tropical storm while centered about $180 \mathrm{n}$ mi southsoutheast of Cabo San Lucas.

Georgette was situated on the western periphery of a deep-layer subtropical ridge situated over northern Mexico. The flow associated with the ridge steered the cyclone on a north-northwestward to northward track at a forward speed of 7 to $12 \mathrm{kt}$ throughout most its lifetime. On 21 September, Georgette approached the southern tip of Baja California and made landfall around 1800 UTC near San Jose del Cabo in the state of Baja California Sur with maximum winds of $35 \mathrm{kt}$. After landfall, Georgette continued northward across southeastern Baja California and weakened to a tropical depression around 0000 UTC 22 September. Shortly after that time, the center moved into the Gulf of California and continued northward with no change in strength. Around 2200 UTC that day, the center made landfall along the west coast of mainland Mexico near San Carlos, west of Guaymas, in the state of Sonora. After this landfall, the low-level circulation moved farther inland and dissipated by 0600 UTC 23 September. Flooding was reported in Empalme, Etchojoa, Navojoa, and Guaymas in the state of Sonora, and 500000 people were evacuated in those areas. Flooding was also reported in the city of Los Mochis in Sinaloa. No monetary damage estimates are available and there were no casualties reported in association with Georgette. 


\section{Tropical depressions}

\section{a. Tropical Depression Two-E, 16-17 June}

Tropical Depression Two-E was a short-lived tropical cyclone that formed south of the Gulf of Tehuantepec and produced locally heavy rainfall along the coast of Mexico as it moved west-northwestward before dissipating. The depression developed from a tropical wave that moved off the west coast of Africa on 2 June and entered the eastern Pacific on 13-14 June. As the wave approached the Gulf of Tehuantepec, convection began to increase in organization and it is estimated that a tropical depression formed around 0600 UTC 16 June about 95 $\mathrm{n}$ mi south of Salina Cruz, Mexico. The depression moved slowly west-northwestward after genesis, and deep convection remained displaced to the west and southwest of the center due to strong northeasterly vertical wind shear. ASCAT data around 1630 UTC 16 June indicated that the intensity had increased to $30 \mathrm{kt}$. However, the convection became disorganized by 0000 UTC 17 June, and geostationary and microwave satellite imagery indicated that the low-level circulation dissipated by 0600 UTC that day.

The depression produced heavy rainfall along portions of the Pacific coast of Mexico. Bahias de Huatulco in the Mexican state of Oaxaca reported $64 \mathrm{~mm}$ of rainfall in the 24-h period ending at 1200 UTC 17 June. According to media reports, 70 to 80 homes were damaged as a result of rain-induced floods in San Juan Bautista Tuxtepec in Oaxaca. Additional damage was reported in Rio Grande and Santa Gertrudis, where 40 and 20 homes were damaged, respectively. There were no casualties associated with the depression.

\section{b. Tropical Depression Six-E, 14-16 July}

The genesis of Tropical Depression Six-E can be traced back to a tropical wave that exited the west coast of Africa on 28 June. The wave crossed Central America and entered the eastern North Pacific Ocean on 9 July, and a broad low pressure area developed along the wave axis south of the coast of Guatemala a couple of days later. Shower and thunderstorm activity increased in association with the broad low on 12 July as it passed south of the Gulf of Tehuantepec. As the low moved west-northwestward off of the southern coast of Mexico, the low-level circulation became better defined. Weakly curved bands of convection formed over the western semicircle of the low early on 14 July and by 1200 UTC that day, when the system was located about $285 \mathrm{n}$ mi south-southwest of Manzanillo, Mexico, it had acquired sufficient convective organization to be considered a tropical depression.

The cyclone initially moved west-northwestward but turned toward the northwest on 15 July, while moderate to strong easterly vertical wind shear prohibited the depression from strengthening. The system moved over cooler waters on 16 July and degenerated to a remnant low by 1800 UTC that day. The nonconvective low turned westward to west-northwestward and continued on this heading until it dissipated about $600 \mathrm{n}$ mi west-southwest of the southern tip of the Baja Peninsula by 1200 UTC 18 July.

\section{c. Tropical Depression Eight-E, 20-21 August}

The disturbance that spawned Tropical Depression Eight-E was a tropical wave that departed the African coast on 3 August. Shower activity formed within the wave envelope over the east-central tropical Atlantic on 6 August, and this disturbance nearly developed into a tropical cyclone as it moved generally northwestward over the next few days. The wave itself continued westward across the Atlantic basin, producing only a few showers. The system crossed Central America on 15 August, and the associated deep convection increased as the wave moved just to the south of Mexico over the next several days. By early on 20 August, thunderstorm activity became better organized near a low-level circulation center, and it is estimated that a tropical depression formed by 0600 UTC that day about $160 \mathrm{n}$ mi west-southwest of Manzanillo, Mexico. A midlevel subtropical ridge over northwestern Mexico forced the depression in a general west-northwestward direction, while strong northeasterly vertical wind shear kept the tropical cyclone from strengthening. Early on 21 August, the depression moved over cooler waters and weakened. After 1200 UTC that day, the system was essentially devoid of deep convection and degenerated into a remnant low pressure system. The low moved slowly west-northwestward to westward and dissipated early on 23 August.

\section{d. Tropical Depression Ten-E, 3-4 September}

Tropical Depression Ten-E formed from a tropical wave that moved off the west coast of Africa on 14 August. The wave was relatively inactive while over the Atlantic Ocean, but it began to develop some moderate convection when it crossed Central America and entered the eastern North Pacific Ocean on 26 August. During the next several days, associated shower and thunderstorm activity remained disorganized and displaced to the west of the wave axis due to strong easterly vertical wind shear. Although convection gradually increased and became better organized on 1 and 2 September, the system did not possess a closed surface circulation at that time. Conventional and microwave satellite data indicated the system developed a well-defined center and enough organized deep convection to be classified as a tropical depression 
TABLE 2. Homogenous comparison of official (OFCL) and CLIPER5 track forecast errors in the eastern North Pacific basin for the 2010 season for all tropical cyclones. Averages for the previous 5-yr period are shown for comparison.

\begin{tabular}{|c|c|c|c|c|c|c|c|}
\hline & \multicolumn{7}{|c|}{ Forecast period $(\mathrm{h})$} \\
\hline & 12 & 24 & 36 & 48 & 72 & 96 & 120 \\
\hline 2010 mean OFCL error (n mi) & 26.0 & 40.1 & 48.6 & 54.7 & 85.3 & 119.3 & 145.4 \\
\hline 2010 mean CLIPER5 error ( $\mathrm{n} \mathrm{mi)}$ & 36.5 & 73.2 & 110.8 & 143.5 & 204.4 & 255.3 & 259.4 \\
\hline 2010 mean OFCL skill relative to CLIPER5 (\%) & 28.8 & 45.2 & 56.1 & 61.9 & 58.3 & 53.3 & 43.9 \\
\hline 2010 mean OFCL bias vector $(\% / \mathrm{mi})$ & $244 / 4$ & $266 / 6$ & $301 / 5$ & $50 / 9$ & $68 / 39$ & $74 / 69$ & $77 / 97$ \\
\hline 2010 number of cases & 138 & 115 & 97 & 83 & 63 & 43 & 29 \\
\hline 2005-09 mean OFCL error (n mi) & 30.8 & 51.5 & 71.6 & 89.6 & 120.9 & 155.0 & 192.0 \\
\hline 2005-09 mean CLIPER5 error (n mi) & 38.9 & 75.3 & 115.7 & 155.8 & 226.9 & 275.1 & 321.5 \\
\hline 2005-09 mean OFCL skill relative to CLIPER5 (\%) & 20.8 & 31.4 & 38.0 & 42.5 & 47.2 & 44.6 & 41.5 \\
\hline 2005-09 mean OFCL bias vector $(\% / \mathrm{n} \mathrm{mi})$ & $308 / 3$ & $297 / 5$ & $283 / 7$ & $282 / 12$ & $260 / 12$ & $241 / 5$ & $109 / 5$ \\
\hline 2005-09 number of cases & 1323 & 1160 & 1001 & 863 & 628 & 448 & 310 \\
\hline 2010 OFCL error relative to $2005-09$ mean (\%) & -15.6 & -22.1 & -33.0 & -39.0 & -29.4 & -23.0 & -24.3 \\
\hline 2010 CLIPER5 error relative to $2005-09$ mean (\%) & -6.2 & -2.8 & -4.2 & -7.9 & -9.9 & -7.2 & -19.3 \\
\hline
\end{tabular}

at 0000 UTC 3 September, when it was located about $220 \mathrm{n}$ mi south-southeast of the southern tip of Baja California.

The depression moved slowly northwestward for the next day or so, steered between a deep-layer subtropical ridge over Mexico and a deep-layer trough over the eastern North Pacific Ocean. The combination of moderate to strong easterly wind shear and a short time over relatively warm water prevented the cyclone from intensifying. The depression moved over cooler waters early on 4 September and became a remnant low pressure system by 1200 UTC that day when located about $160 \mathrm{n} \mathrm{mi} \mathrm{west-southwest} \mathrm{of} \mathrm{the} \mathrm{southern} \mathrm{tip} \mathrm{of} \mathrm{Baja}$ California. The remnant low continued northwestward for the next day or so before dissipating.

\section{e. Tropical Depression Eleven-E, 3-4 September}

Tropical Depression Eleven-E developed from the southern portion of a tropical wave that initiated Hurricane Danielle in the eastern tropical Atlantic, and remnants of the depression were later responsible for the genesis of Tropical Storm Hermine (Beven and Blake 2012). The southern portion of the wave continued westward at low latitudes across the tropical Atlantic and northern South America, and reached the eastern North Pacific on 29 August. The associated convection remained mostly over Central America until 2 September, when it increased significantly over the Gulf of Tehuantepec and the adjacent Pacific waters. A surface circulation gradually developed, and it is estimated that a tropical depression formed near 1800 UTC 3 September about $100 \mathrm{n} \mathrm{mi}$ southeast of Salina Cruz, Mexico.

After genesis, the depression moved northwestward across the Gulf of Tehuantepec and made landfall near Salina Cruz around 0700 UTC 4 September. The cyclone turned northward after landfall and degenerated into a low pressure area later that day over the Isthmus of Tehuantepec. The low continued northward into the Bay of Campeche on 5 September, where it redeveloped and became Atlantic Tropical Storm Hermine.

The cargo ship Aida (call sign SBLI) reported tropicalstorm-force winds four times on 3-4 September, including two reports well after landfall and well to the west of the center. However, these data suggest that those winds were more associated with a westerly monsoon flow west and south of the depression rather than directly associated with the cyclone's circulation.

There were no reports of casualties or damage directly related to the depression. However, the moist monsoon flow produced heavy rains over portions of Central America, which created mud slides that caused 38 deaths in Guatemala.

\section{Forecast verification and warnings}

For all operationally designated tropical cyclones in its area of responsibility, the NHC issues an official tropical cyclone track (latitude and longitude of the circulation center) and intensity (maximum 1 -min wind speed at $10 \mathrm{~m}$ above the surface) forecast every $6 \mathrm{~h}$. These forecasts are made for the 12-, 24-, 36-, 48-, 72-, 96-, and 120-h periods from the initial synoptic time of the forecast $(0000,0600$, 1200 , or 1800 UTC). The forecasts are evaluated using the postseason 6-hourly best track database for all tropical cyclones. The track error is defined as the great-circle distance between forecast and best track positions of the tropical cyclone center; the intensity error is the absolute value of the difference between the forecast and best track intensities. 
TABLE 3. Homogenous comparison of official (OFCL) and Decay-SHIFOR5 intensity forecast errors in the eastern North Pacific basin for the 2010 season for all tropical cyclones. Averages for the previous 5-yr period are shown for comparison.

\begin{tabular}{|c|c|c|c|c|c|c|c|}
\hline & \multicolumn{7}{|c|}{ Forecast period $(\mathrm{h})$} \\
\hline & 12 & 24 & 36 & 48 & 72 & 96 & 120 \\
\hline 2010 mean OFCL error $(\mathrm{kt})$ & 6.1 & 9.3 & 12.4 & 13.5 & 15.6 & 15.9 & 17.8 \\
\hline 2010 mean Decay-SHIFOR5 error $(\mathrm{kt})$ & 8.0 & 12.7 & 17.4 & 20.0 & 23.8 & 24.7 & 31.2 \\
\hline 2010 mean OFCL skill relative to Decay-SHIFOR5 (\%) & 26.7 & 24.8 & 33.9 & 41.0 & 38.0 & 36.2 & 37.3 \\
\hline 2010 OFCL bias (kt) & 1.2 & 1.6 & 2.1 & 1.6 & 1.0 & 2.0 & -1.2 \\
\hline 2010 number of cases & 138 & 115 & 97 & 83 & 63 & 43 & 29 \\
\hline 2005-09 mean OFCL error $(\mathrm{kt})$ & 6.2 & 10.4 & 13.7 & 15.4 & 17.2 & 18.6 & 18.4 \\
\hline 2005-09 mean Decay-SHIFOR5 error (kt) & 7.1 & 11.6 & 15.0 & 17.5 & 18.8 & 19.5 & 19.2 \\
\hline 2005-09 mean OFCL skill relative to Decay-SHIFOR5 (\%) & 12.7 & 10.3 & 8.7 & 12.0 & 8.5 & 4.6 & 4.2 \\
\hline 2005-09 OFCL bias $(\mathrm{kt})$ & 0.6 & 1.1 & 1.1 & 0.0 & -0.5 & -2.6 & -4.7 \\
\hline 2005-09 number of cases & 1296 & 1135 & 978 & 842 & 611 & 435 & 301 \\
\hline 2010 OFCL error relative to $2005-09$ mean (\%) & -1.6 & -10.6 & -9.5 & -12.3 & -9.3 & -14.5 & -3.3 \\
\hline 2010 Decay-SHIFOR5 error relative to 2005-09 mean (\%) & 12.7 & 9.5 & 16.0 & 14.3 & 26.6 & 26.7 & 62.5 \\
\hline
\end{tabular}

A comparison of the average track errors for 2010 and the previous 5-yr period for the official forecast and the CLIPER5 $^{2}$ (Neumann 1972; Aberson 1998) model forecast are shown in Table 2, after Cangialosi and Franklin (2011). CLIPER5 serves as a benchmark of track forecast skill. Track forecast accuracy for 2010 was exceptionally good. Mean track errors ranged from $26 \mathrm{n}$ mi at $12 \mathrm{~h}$ to $145 \mathrm{n} \mathrm{mi}$ at $120 \mathrm{~h}$ and were consistently lower (between $15 \%$ and $39 \%$ ) than the 5 -yr means. New records were set at all forecast times.

CLIPER5 errors were below their long-term means, implying that forecast difficulty in 2010 was lower than normal. Forecast biases were near average from 12 to $48 \mathrm{~h}$ but much larger than average from 72 to $120 \mathrm{~h}$; biases at the latter times were about $60 \%$ of the mean error magnitude and directed toward the east-northeast. Tropical Storm Blas and Hurricane Frank were major contributors to these biases.

Table 3 (Cangialosi and Franklin 2011) compares official forecasts to the Decay-SHIFOR5 (see footnote 2; Jarvinen and Neumann 1979; Knaff et al. 2003) model that serves as a benchmark of intensity forecast skill. Average official intensity forecast errors were $6 \mathrm{kt}$ at $12 \mathrm{~h}$ and increased to $18 \mathrm{kt}$ by $120 \mathrm{~h}$. These errors were smaller than the 5 -yr means, by up to $15 \%$, at all forecast times. The SHIFOR5 forecast errors were significantly larger than their 5-yr means; this implies that forecast difficulty in 2010 was higher than normal. All-time low errors were set at $72-96 \mathrm{~h}$. A review of error and skill trends (not shown) indicates that NHC forecast skill in 2010 was at the highest point on record at all forecast

\footnotetext{
${ }^{2}$ CLIPER5 and SHIFOR5 are 5-day versions of the original Climatology and Persistence (CLIPER) and Statistical Hurricane Intensity Forecast (SHIFOR) models.
}

times, albeit for a small sample. Intensity forecast biases in 2010 were small.

Acknowledgments. The cyclone summaries are based on Tropical Cyclone Reports written by the authors, along with those produced by Lixion Avila, Robbie Berg, John L. Beven II, Eric Blake, Michael Brennan, Daniel Brown, Richard Pasch, and Todd Kimberlain of NHC. These reports are available online at http:// www.nhc.noaa.gov/2010epac.shtml. Ethan Gibney of the I.M. Systems Group at the NOAA Coastal Services Center produced the track chart (Fig. 1). Gerry Bell of the NOAA Climate Prediction Center produced Figs. 2, 3 , and 4 .

\section{REFERENCES}

Aberson, S. D., 1998: Five-day tropical cyclone track forecasts in the North Atlantic basin. Wea. Forecasting, 13, 1005-1015.

Bell, G. D., and Coauthors, 2000: Climate assessment for 1999. Bull. Amer. Meteor. Soc., 81, S1-S50.

Beven, J. L., II, and E. S. Blake, 2012: Atlantic Hurricane season of 2010. Mon. Wea. Rev., in press.

Brennan, M. J., C. C. Hennon, and R. D. Knabb, 2009: The operational use of QuikSCAT ocean surface vector winds at the National Hurricane Center. Wea. Forecasting, 24, 621-645.

Brueske, K. F., and C. S. Velden, 2003: Satellite-based tropical cyclone intensity estimation using the NOAA-KLM series Advanced Microwave Sounding Unit (AMSU). Mon. Wea. Rev., 131, 687-697.

Cangialosi, J. P., and J. F. Franklin, 2011: 2010 National Hurricane Center Forecast verification report. National Hurricane Center, 77 pp. [Available online at http://www.nhc.noaa.gov/verification/ pdfs/Verification_2010.pdf.]

Demuth, J. L., M. DeMaria, and J. A. Knaff, 2006: Improvement of Advanced Microwave Sounding Unit tropical cyclone intensity and size estimation algorithms. J. Appl. Meteor. Climatol., 45, 1573-1581. 
Dvorak, V. F., 1984: Tropical cyclone intensity analysis using satellite data. NOAA Tech. Rep. NESDIS 11, 47 pp.

Hawkins, J. D., T. Lee, J. Turk, C. Sampson, J. Kent, and K. Richardson, 2001: Real-time internet distribution of satellite products for tropical cyclone reconnaissance. Bull. Amer. Meteor. Soc., 82, 567-578.

Herndon, D., and C. S. Velden, 2004: Updates to the UW-CIMSS AMSU-based TC intensity algorithm. Preprints, 26th Conf. on Hurricanes and Tropical Meteorology, Miami, FL, Amer. Meteor. Soc., 118-119.

Jarvinen, B. R., and C. J. Neumann, 1979: Statistical forecasts of tropical cyclone intensity for the North Atlantic basin. NOAA Tech. Memo. NWS NHC-10, 22 pp.

Kalnay, E., and Coauthors, 1996: The NCEP/NCAR 40-Year Reanalysis Project. Bull. Amer. Meteor. Soc., 77, 437-471.

Knaff, J. A., M. DeMaria, B. Sampson, and J. M. Gross, 2003: Statistical, 5-day tropical cyclone intensity forecasts derived from climatology and persistence. Wea. Forecasting, 18, 80-92.

Neumann, C. B., 1972: An alternate to the HURRAN (hurricane analog) tropical cyclone forecast system. NOAA Tech. Memo. NWS SR-62, 24 pp.
Olander, T. L., and C. S. Velden, 2007: The advanced Dvorak technique: Continued development of an objective scheme to estimate tropical cyclone intensity using geostationary infrared satellite imagery. Wea. Forecasting, 22, 287-298.

Rappaport, E. N., and Coauthors, 2009: Advances and challenges at the National Hurricane Center. Wea. Forecasting, 24, 395419.

Saffir, H. S., 1973: Hurricane wind and storm surge. Mil. Eng., 423, 4-5.

Schott, T., and Coauthors, cited 2012: The Saffir-Simpson Hurricane Wind Scale. [Available online at http://www.nhc.noaa.gov/pdf/ sshws.pdf.]

Simpson, R. H., 1974: The hurricane disaster potential scale. Weatherwise, 27, 169, 186.

Velden, C., and Coauthors, 2006: The Dvorak tropical cyclone intensity estimation technique: A satellite-based method that has endured for over 30 years. Bull. Amer. Meteor. Soc., 87, $1195-1210$

Wang, C., and S.-K. Lee, 2009: Co-variability of tropical cyclones in the North Atlantic and the eastern North Pacific. Geophys. Res. Lett., 36, L24702, doi:10.1029/2009GL041469. 
Copyright of Monthly Weather Review is the property of American Meteorological Society and its content may not be copied or emailed to multiple sites or posted to a listserv without the copyright holder's express written permission. However, users may print, download, or email articles for individual use. 